\title{
The effects of environmental enrichment on some welfare indicators in fattening cattle, housed at different stocking densities
}

\author{
Kristina Matkovićc ${ }^{*}$, Ranka Šimićć, Marica Lolić ${ }^{3}$, and Mario Ostovićc \\ ${ }^{1}$ Department of Animal Hygiene, Behaviour and Welfare, Faculty of Veterinary Medicine, University of Zagreb, \\ Zagreb, Croatia \\ ${ }^{2}$ Veterinary and Food Safety Directorate, Ministry of Agriculture, Zagreb, Croatia \\ ${ }^{3}$ Croatian Veterinary Institute, Veterinary Department Vinkovci, Vinkovci, Croatia
}

MATKOVIĆ, K., R. ŠIMIĆ, M. LOLIĆ, M. OSTOVIĆ: The effects of environmental enrichment on some welfare indicators in fattening cattle, housed at different stocking densities. Vet. arhiv 90, 575-582, 2020.

\section{ABSTRACT}

The effects of environmental enrichment were assessed at different stocking densities on fattening cattle welfare. The study included four groups of heifers observed during four-month final commercial fattening. The heifers were housed in non-enriched and enriched environments at low $\left(\mathrm{n}=14 ; 4.5 \mathrm{~m}^{2} /\right.$ animal $)$ and high $(\mathrm{n}=19 ; 3.3 \mathrm{~m} / \mathrm{animal})$ stocking density. Environmental enrichment consisted of a grooming brush and salt blocks. Heifer welfare was assessed using selected indicators from the Welfare Quality ${ }^{\circledR}$ assessment protocol for cattle. The study results showed that the heifers housed at high stocking density used environmental enrichment materials significantly more frequently as compared with heifers housed at low stocking density $(\mathrm{P}<0.05)$, whereas there was no difference in their use of particular enrichment materials. The effect of environmental enrichment on heifer welfare was mainly manifested in a reduction in the expression of some forms of aggressive behaviour; therefore, this finding should encourage the use of enrichment materials such as those presented in this study which are commercially available, relatively inexpensive and simple to use.

Key words: fattening cattle; environmental enrichment; grooming brush; salt block; stocking density; animal welfare

\section{Introduction}

Humane treatment of food animals and ensuring appropriate conditions throughout animal life and production process are substantial elements in food quality and safety (GREGORY, 2007). Animal health and welfare are the result of complex interactions between each animal and the farm environment, primarily depending on farm management practices (SUNDRUM et al., 2006). Recently, the debate on animal welfare has been increasingly focused on the factors that result in abnormal, unwanted behaviours in cattle kept in intensive farming systems (EFSA, 2012; TUCKER, 2018).

\footnotetext{
*Corresponding author:

Prof. Kristina Matković, PhD, DVM, Department of Animal Hygiene, Behaviour and Welfare, Faculty of Veterinary Medicine, University of Zagreb, Heinzelova 55, 10000 Zagreb, Croatia, Phone: +385 12390 292; Fax: +385 12441 390; E-mail: kmatkov@vef.hr
} 
Reaching high standards in animal welfare is also an important issue for stockbreeders, since in the European Union (EU) member countries, they are able to receive incentives to upgrade animal welfare standards from the minimum regulated or recommended standards. In addition, consumers, including Croatian consumers, are ready to pay more for products coming from such upgraded systems (CERJAK et al., 2011; MIKUŠ et al., 2017).

The EU legislature provides a legal framework based on scientific research, that determines minimal welfare conditions for animals raised and kept for food production. However, apart from numerous recommendations and opinions, there are no legal provisions regulating specific conditions in fattening cattle housing. GOESSENS (2013) reports that agricultural organisations are ready to take measures to improve farm animal welfare and in collaboration with scientific institutions, they are looking for an alternative approach to ensure the highest possible level of animal welfare. The multidimensional nature of animal welfare requires a large number of parameters to be included in its assessment (DUNCAN, 2002; BOTREAU et al., 2007; BLOKHUIS et al., 2013), considering that housing quality, determined by factors of the microclimate, floor type, stocking density, movement conditions, feeding and watering systems, etc., influences fattening cattle welfare the most (EFSA, 2012).

Environmental enrichment is an accepted method of upgrading animal welfare. It is defined as a modification of the breeding environment aimed at improving the animals' biological functioning (NEWBERRY, 1995), and stimulating expression of species specific behaviours and mental activities (REINHARDT and REINHARDT, 2002; MATKOVIĆ et al., 2016). Thus, environmental enrichment helps animals cope with various stressors, while reducing their frustration and boredom (MANDEL et al., 2016). Efficient environmental enrichment is expected to upgrade animal welfare, exert favourable effects on production system economics, and be simple to use (PAVIČIĆ and OSTOVIĆ, 2019).
Unlike other species and categories of farm animals kept in intensive farming systems, for which compulsory environmental enrichment has been legally regulated, e.g., laying hens and pigs, the effect of enriched environment on fattening cattle welfare has been assessed in only a few studies to date.

The aim of this study was to assess the effect of an enriched environment on the welfare of fattening cattle, housed at different stocking densities.

\section{Materials and methods}

The study was conducted at a commercial farm for final cattle fattening, and included 66 one-year old heifers observed for four months (FebruaryMay). The heifers were divided into four groups of mixed breeds (Simmental, Charolais, Belgian Blue, Hereford). The entry weight of heifers was approximately $250 \mathrm{~kg}$ and the final weight 450 $\mathrm{kg}$. Two groups of heifers were kept in standard production conditions without environmental enrichment, in a half-open stable, on a solid bedded floor, with $\sim 3.5 \mathrm{~kg}$ straw per animal daily. In one of these groups (low stocking density, no enrichment, LSDNE), stocking density was $4.5 \mathrm{~m}^{2}$ /animal (14 animals in a pen measuring $5.2 \mathrm{~m} \mathrm{x} 12 \mathrm{~m}$ ), whereas in the other group (high stocking density, no enrichment, HSDNE), stocking density was $3.3 \mathrm{~m}^{2} /$ animal (19 animals in a pen of the same size). Each pen was supplied with two automatic drinkers and a 12-m feeding trough. The remaining two groups of heifers were kept in the same conditions and at the same stocking densities, but with additional environmental enrichment (low stocking density with enrichment, LSDWE and high stocking density with enrichment, HSDWE). In these groups, their environment was enriched with a mechanical grooming brush (Albert Kerbl GmbH, Germany) and two salt blocks (Royal İlaç, Turkey). The grooming brush was placed on the wall in the middle of the pen, thus enabling them to scratch their withers and sides, while salt blocks were placed in the feeding trough and replaced as needed (Figs 1 and 2). The heifers were fed ad libitum, their feed containing super concentrate $(8.61 \%)$, sodium bicarbonate $(0.05 \%)$, straw $(1.59 \%)$, green silage $(45.11 \%)$, corn grits $(29.19 \%)$ and beet pulp (15.92\%). 
Heifer welfare was assessed according to selected indicators from the Welfare Quality ${ }^{\circledR}$ assessment protocol for cattle (WELFARE QUALITY ${ }^{\circledR}, 2009$ ). The following indicators were investigated: head butt, displacement, chasing, fighting, chasingup, social licking, horning, lying and avoidance distance, body condition, hairless patches on body and legs, lesions and swelling, and cleanliness of animals. Determination of the frequency of manifestation of these indicators was undertaken for 2 hours of observation weekly. Use of the grooming brush and salt blocks was counted in parallel with the assessment of the study indicators. Grooming brush usage was recorded when an animal used it for more than 5 seconds, and salt block usage when an animal licked it for more than 3 seconds. Expression of the same or different behaviour was recorded for each individual animal on several

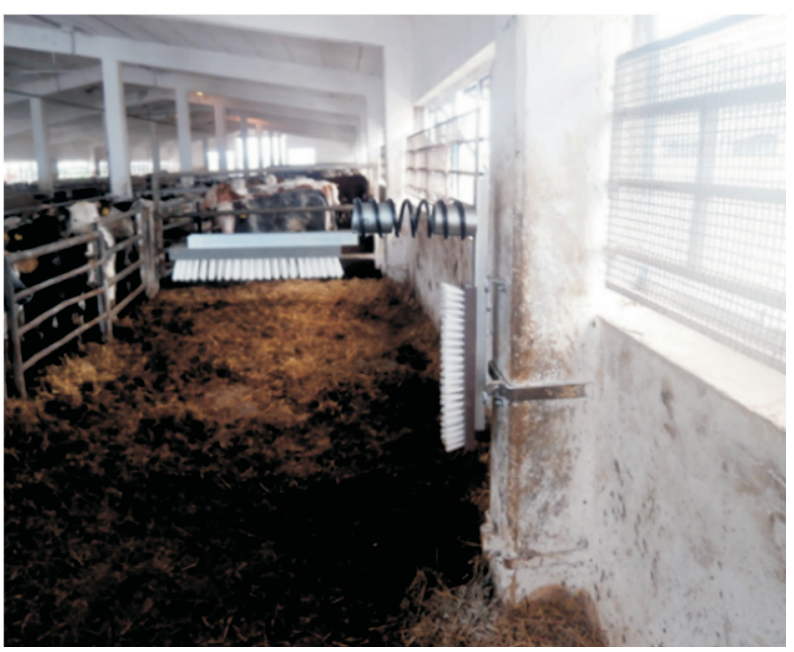

occasions. All other indicators were assessed once for each animal throughout the weekly observation periods. All study procedures were performed by the same experienced professionals.

Data analysis was performed using Statistica v. 13.5 (TIBCO Software Inc., 2019). Between-group differences in behaviour, body condition, hairless patches, lesions and swelling, and cleanliness were tested by the $\chi^{2}$-test and the Fisher exact test. Differences in the use of particular environmental enrichment materials, according to groups and fattening months, were tested by the Kruskal-Wallis test and the Mann-Whitney $U$-test. Correlations between the use of enrichment materials and the values of other study indicators were determined by Spearman Rank Order Correlations. The level of statistical significance of differences was set at $\mathrm{P}<0.05$.

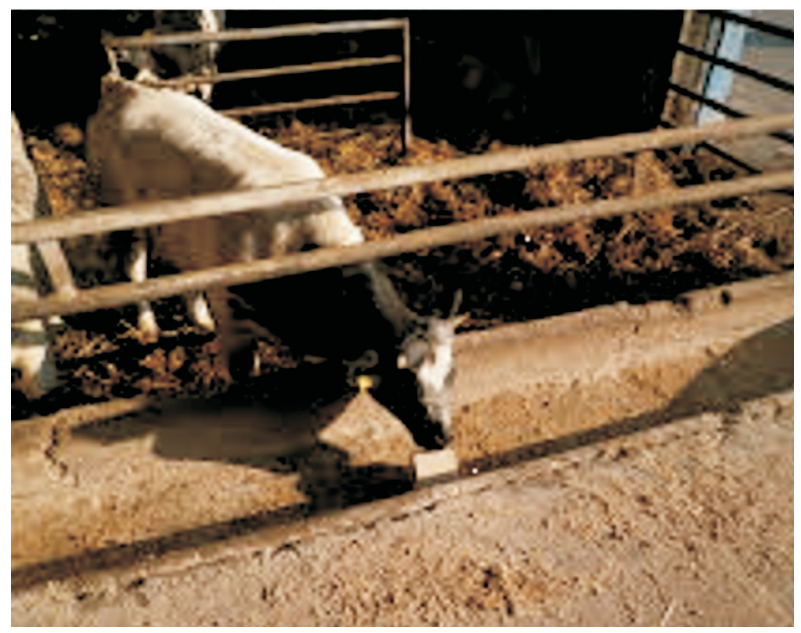

Figs. 1 and 2. Environmental enrichment materials used in the study: mechanical grooming brush and salt blocks

\section{Results}

As shown in Table 1, there were no significant differences in use of the grooming brush or salt blocks between the groups of heifers housed at low and high stocking density in any of the fattening months observed. There were also no significant within-group differences in use of particular environmental enrichment materials between the fattening months. The overall frequency of use of particular enrichment materials in both groups of animals housed at low and high stocking density throughout the fattening period also did not yield any significant differences in animal use of the grooming brush and salt blocks. However, the overall frequency of use of both the grooming brush and salt blocks throughout the fattening period according to animal groups showed that the group of heifers housed at high stocking density used the enrichment materials significantly more frequently $(\mathrm{P}<0.05)$. 
Matković et al.: Environmental enrichment, stocking density and fattening cattle welfare

Table 1. Frequency of use of the grooming brush and salt blocks as enrichment materials in groups of heifers housed at low and high stocking density during a four-month final fattening period

\begin{tabular}{|l|c|c|c|c|}
\hline \multirow{2}{*}{$\begin{array}{l}\text { Fattening } \\
\text { month }\end{array}$} & $\begin{array}{c}\text { LSD } \\
(\mathrm{n}=14)\end{array}$ & $\begin{array}{c}\text { GSD } \\
(\mathrm{n}=19)\end{array}$ & $\begin{array}{c}\text { LSD } \\
(\mathrm{n}=14)\end{array}$ & $\begin{array}{c}\text { Salt blocks } \\
(\mathrm{n}=19)\end{array}$ \\
\hline First & 20 & 25 & 20 & 22 \\
\hline Second & 19 & 18 & 21 & 21 \\
\hline Third & 17 & 23 & 17 & 17 \\
\hline Fourth & 16 & 26 & 13 & 18 \\
\hline$\sum$ & 72 & 92 & 71 & 78 \\
\hline
\end{tabular}

LSD - low stocking density, HSD - high stocking density. Results are expressed as the total number of particular enrichment material usage according to heifer groups and fattening months

Table 2. Comparison of the values of study indicators between heifer groups

\begin{tabular}{|c|c|c|c|c|}
\hline Indicator & $\begin{array}{l}\text { LSDNE } \\
(\mathrm{n}=14)\end{array}$ & $\begin{array}{l}\text { HSDNE } \\
(n=19)\end{array}$ & $\begin{array}{l}\text { LSDWE } \\
(\mathrm{n}=14)\end{array}$ & $\begin{array}{c}\text { HSDWE } \\
(\mathrm{n}=19)\end{array}$ \\
\hline Head butting & $21^{\mathrm{a}, \mathrm{b}, \mathrm{c}}$ & $5^{\mathrm{a}}$ & $4^{b}$ & $5^{c}$ \\
\hline Displacement & 35 & 52 & 14 & 32 \\
\hline Chasing & $53^{\mathrm{a}}$ & $59^{\mathrm{b}, \mathrm{c}}$ & $10^{\mathrm{a}, \mathrm{b}}$ & $32^{\mathrm{c}}$ \\
\hline Fighting & 6 & 11 & 0 & 1 \\
\hline Chasing-up & 6 & 8 & 3 & 4 \\
\hline Social licking & 69 & 54 & 100 & 119 \\
\hline Horning & 54 & 40 & 73 & 83 \\
\hline Lying & 161 & 150 & 148 & 150 \\
\hline Avoidance distance 0 & 28 & 16 & 26 & 28 \\
\hline Avoidance distance 1 & 66 & 62 & 53 & 64 \\
\hline Avoidance distance 2 & 73 & 114 & 64 & 101 \\
\hline Avoidance distance 3 & $54^{\mathrm{a}}$ & $112^{\mathrm{a}}$ & 86 & 108 \\
\hline Body condition score 0 & 224 & 304 & 224 & 334 \\
\hline Hairless patches on body & 14 & 27 & 18 & 27 \\
\hline Hairless patches on legs & 38 & 54 & 29 & 54 \\
\hline Lesions & 0 & 12 & 0 & 12 \\
\hline Swelling & 7 & 2 & 4 & 2 \\
\hline Cleanliness of animals 0 & 61 & 67 & 52 & 67 \\
\hline Cleanliness of animals 2 & 49 & $62^{\mathrm{a}}$ & $25^{\mathrm{a}, \mathrm{b}}$ & $62^{b}$ \\
\hline
\end{tabular}

LSDNE - low stocking density with no enrichment, HSDNE - high stocking density with no enrichment, LSDWE low stocking density with enrichment, HSDWE - high stocking density with enrichment. a,b,c Values in the same row marked with the same letter differ significantly $(\mathrm{P}<0.05)$ Results are expressed as the total number of observations in particular heifer groups throughout the study period 
As shown in Table 2, the rate of head butting was significantly higher in the group of heifers housed at low stocking density without environmental enrichment as compared with all the other study groups $(\mathrm{P}<0.05)$. The rate of chasing was significantly higher in the group of heifers housed at high stocking density without environmental enrichment in comparison to both heifer groups housed in an enriched environment $(\mathrm{P}<0.05)$. A higher rate of chasing was also recorded in the group of heifers housed at low stocking density without environmental enrichment, in comparison to the group of heifers housed at the same stocking density with an enriched environment $(\mathrm{P}<0.05)$. Considering the avoidance distance indicator, a difference in score 3 was found between the groups of heifers housed in a non-enriched environment, where the animals could not be approached as close as $100 \mathrm{~cm}$ significantly more frequently at high stocking density as compared with the heifers housed at low stocking density $(\mathrm{P}<0.05)$. In the groups of heifers housed at high stocking density, both with and without environmental enrichment, $\geq 25 \%$ of the area covered with plaque or $>50 \%$ of the area covered with liquid dirt was recorded significantly more frequently as compared with the group of heifers housed at low stocking density with environmental enrichment. There were no significant between-group differences in the indicators of displacement, fighting, chasing-up, social licking, horning and lying, body condition, hairless patches on body and legs, lesions and swelling.

Significant positive correlations $(\mathrm{P}<0.05)$ were found between the use of environmental enrichment materials and other indicators, as follows: using salt blocks with displacement and lying, and using the grooming brush with hairless patches on legs $(\mathrm{P}<0.05)$ (Table 3).

Table 3. Correlations between enrichment material use and the values of other study indicators

\begin{tabular}{|l|c|c|}
\hline \multicolumn{1}{|c|}{ Indicator } & Grooming brush usage & Salt block usage \\
\hline Head butting & -0.084 & 0.000 \\
\hline Displacement & 0.323 & 0.123 \\
\hline Chasing & 0.226 & - \\
\hline Fighting & - & -0.290 \\
\hline Chasing-up & -0.339 & 0.220 \\
\hline Social licking & 0.006 & -0.062 \\
\hline Horning & 0.221 & $0.349 *$ \\
\hline Lying & 0.169 & 0.086 \\
\hline Avoidance distance 0 & 0.185 & -0.070 \\
\hline Avoidance distance 1 & 0.228 & 0.129 \\
\hline Avoidance distance 2 & 0.279 & 0.168 \\
\hline Avoidance distance 3 & 0.043 & 0.171 \\
\hline Body condition score 0 & 0.336 & 0.050 \\
\hline Hairless patches on body & 0.059 & -0.012 \\
\hline Hairless patches on legs & $0.526 *$ & -0.108 \\
\hline Lesions & -0.096 & 0.275 \\
\hline Swelling & -0.181 & -0.191 \\
\hline Cleanliness of animals 0 & -0.019 & 0.244 \\
\hline Cleanliness of animals 2 & 0.123 & \\
\hline
\end{tabular}

$* \mathrm{P}<0.05$ 


\section{Discussion}

Considering the growing public concern in relation to the conditions of farm animal housing and breeding, environmental enrichment has made a major breakthrough towards improvement of their welfare (MATKOVIĆ et al., 2016). Numerous studies have focused on the effects of enriched environment on animal behaviour, and investigated various types of environmental enrichment. Research results have revealed that the best success in farm animals was achieved with structural enrichment materials, whereas sensorial, social, nutritional and cognitive forms of enrichment were less successful (DE AZEVEDO et al., 2007). NEWBY et al. (2013) report that cattle scratching against some objects is a natural activity that reduces stress, and cattle in intensive production systems reduce boredom and frustration by scratching, which can improve their welfare (DEVRIES et al., 2007). WILSON et al. (2002) demonstrated that fattening heifers are more interested in objects that provide grooming as compared with other types of enrichment. Besides using it for grooming, a moveable scratching device stimulated heifers to play with it, expressing behaviour typical for playing.

In the present study, the heifers housed at high stocking density used the enrichment materials more frequently than the heifers housed at low stocking density, however, without differences in use of these materials according to fattening months. We can speculate that high stocking density causes frustration, thus potentiating the use of enrichment materials independently of fattening months.

Previous studies have shown that fattening cattle spend a great deal of time using brushes, which represent sensorial enrichment (WILSON et al., 2002; ISHIWATA et al., 2006). Our results indicated that heifers used the grooming brush as frequently as salt blocks. In addition, we found a significant positive correlation between grooming brush usage and hairless patches on legs, which could be explained by better grooming of the body parts within reach of the brush.

PELLEY et al. (1995) stated that salt/mineral blocks meet both cattle's nutritional requirements and their need for exploring the environment and play. Our study results showed a significant positive correlation between using salt blocks and displacement as a form of aggressive behaviour, which could be explained by the heifers' high interest in approaching the salt blocks. A significant positive correlation was also recorded between using salt blocks and lying down, which could be explained by the previously mentioned correlation, i.e. the heifers' need for rest following aggressive interactions. In addition, these correlations could also explain the finding of significantly more dirty heifers at high stocking density as compared with low stocking density in an enriched environment, suggesting that the former animals spent more time resting and lying down, thus becoming more dirty, after competitive behaviour while trying to reach the enrichment materials, especially in the group at high stocking density, although there were no differences in lying behaviour on the basis of the observation period used in the study.

Animals generate interactions and environmental control through their behaviour, therefore behaviour is their frontline defence against changes that occur in their surroundings (MENCH et al., 1998). According to BROOM (1999), through their behaviour, animals demonstrate the state of their welfare, its main components being behaviours that express playing and positive social relationships. TUCKER (2014) reports that aggressive behaviour in cattle includes threat, such as head lowering to present horns, and it can escalate to physical contact, head butting the head or body of another animal, or chasing. In the present study, there were no between-group differences in the expression of cohesive behaviours, social licking and horning, and in particular forms of aggressive behaviour, displacement, fighting and chasing. However, differences were recorded in aggressive behaviour in the form of head butting and chasing, which were significantly more pronounced in the non-enriched than in the enriched environment. The results obtained could be explained by the fact that heifers housed in an enriched environment spent some time using the enrichment materials, exploring the environment and were less bored, thus spending less time on aggressive interactions, which is consistent with the studies conducted by PELLEY et al. (1995) and BOTREAU et al. (2007).

BOIVIN et al. (2003) emphasised the ethical role of human to animal relationships in the context 
of animal care, welfare and productivity. Cattle with long-term exposure to poor treatment were found to be able to predict such treatment and partially adapt to them (PETHERICK et al., 2009). In addition, previous studies have shown a flight test to be useful in animal behaviour assessment, in both individually and group-housed animals (MAZUREK et al., 2011). Also, animals housed in an environment enriched with mechanical brushes were found to need a smaller flight zone (HEMSWORTH and COLEMAN, 2011). In our study, we employed a distance test according to the Welfare Quality ${ }^{\circledR}$ assessment protocol for cattle (WELFARE QUALITY ${ }^{\circledR}, 2009$ ) to assess the human-animal relationship. There were no between-group differences in the avoidance distance scores 0,1 and 2, i.e. animals that could be touched, approached closer than $50 \mathrm{~cm}$ but not touched, and animals that could be approached as close as 100 to $50 \mathrm{~cm}$, respectively. However, the assessor could approach as close as $100 \mathrm{~cm}$ (score 3) significantly more heifers housed at low stocking density as compared with high stocking density in a non-enriched environment, whereas no such between-group differences at low and high stocking density were recorded in the enriched environment. This could be explained by animal fear and the easier approach to animals at low stocking density, whereas the nonexistence of between-group differences in avoidance distance in the enriched environment could be attributed to better animal adaptation to novelties in their environment, including humans.

During the four-month fattening period, body condition, the rate of hairless patches on the body and legs, and lesions and swellings, were also investigated but no between-group differences were recorded in these indicators.

\section{Conclusions}

The results of this study investigating the effects of environmental enrichment at different stocking densities on fattening cattle welfare showed that heifers used enrichment materials at high stocking density, in particular. Although environmental enrichment had no effect on the majority of study indicators, expression of some forms of aggressive behaviour in heifers was reduced. Considering that the environmental enrichment materials used in the present study are commercially available, relatively inexpensive and simple to use, this finding should encourage their implementation in practice.

\section{Conflicts of Interest}

The authors declare no conflict of interest.

\section{References}

BLOKHUIS, H. J., M. MIELE, I. VEISSIER, J. BRYAN (2013): Improving Farm Animal Welfare: Science and Society Working Together: the Welfare Quality Approach. Wageningen Academic Publishers, Wageningen, The Netherlands.

BOIVIN, X., J. LENSINK, C. TALLET, I. VEISSIER (2003): Stockmanship and farm animal welfare. Anim. Welf. 12, 479-492.

BOTREAU, R., I. VEISSIER, A. BUTTERWORTH, M. B. M. BRACKE, L. J. KEELING (2007): Definition of criteria for overall assessment of animal welfare. Anim. Welf. 16, 225-228.

BROOM, D. M. (1999): Animal welfare: the concept and the issues. In: Attitudes to Animals: News in Animal Welfare. (Dolins, F. L., Ed.), Cambridge University Press, Cambridge, UK, pp. 129-142.

CERJAK, M., D. KAROLYI, Ž. MESIĆ (2011): Consumers' attitudes towards farm animal welfare and their influence on meat consumption. Agric. Conspec. Sci. 76, 283-286.

DE AZEVEDO, C. S., C. F. CIPRESTE, R. J. YOUNG (2007): Environmental enrichment: a GAP analysis. Appl. Anim. Behav. Sci. 102, 329-343.

DOI: 10.1016/j.applanim.2006.05.034

DEVRIES, T. J., M. VANKOVA, D. M. VEIRA, M. A. G. VON KEYSERLINGK (2007): Usage of mechanical brushes by lactating dairy cows. J. Dairy Sci. 90, 2241-2245.

DOI: $10.3168 /$ jds.2006-648

DUNCAN, I. J. H. (2002): Poultry welfare: science or subjectivity? Br. Poult. Sci. 43, 643-652.

DOI: $10.1080 / 0007166021000025109$

EFSA (2012): Scientific opinion on the welfare of cattle kept for beef production and the welfare in intensive calf farming systems. EFSA Panel on Animal Health and Welfare (AHAW). EFSA J. 10, 1-166.

DOI: $10.2903 /$ j.efsa.2012.2669

GOESSENS, I. (2013): Robust weaner pig housing. Management en techniek 18, 18-20 (in Dutch).

GREGORY, N. G. (2007): Animal Welfare and Meat Production. $2^{\text {nd }}$ ed., N. G. Gregory, Cromwell, Trowbridge, UK.

HEMSWORTH, P. H., G. J. COLEMAN (2011): HumanLivestock Interactions: the Stockperson and the Productivity and Welfare of Intensively Farmed Animals. $2^{\text {nd }}$ ed., CAB International, Wallingford, UK. 
ISHIWATA, T., K. UETAKE, N. ABE, Y. EGUCHI, T. TANAKA (2006): Effects of an environmental enrichment using a drum can on behavioral, physiological and productive characteristics in fattening beef cattle. Anim. Sci. J. 77, 352-362.

DOI: $10.1111 / \mathrm{j} .1740-0929.2006 .00359 . x$

MANDEL, R., H. R. WHAY, E. KLEMENT, C. J. NICOL (2016): Environmental enrichment of dairy cows and calves in indoor housing. J. Dairy Sci. 99, 1695-1715. DOI: $10.3168 /$ jds.2015-9875

MATKOVIĆ, K., R. ŠIMIĆ, Ž. PAVIČIĆ, M. OSTOVIĆ (2016): Welfare and behaviour of fattening cattle in enriched environment. Book of Abstracts of the $23^{\text {rd }}$ International Conference Krmiva 2016, 1-3 June, Opatija, Croatia, p. 32. (in Croatian)

MAZUREK, M., M. MCGEE, M. A. CROWE, D. J. PRENDIVILLE, X. BOIVIN, B. EARLEY (2011): Consistency and stability of behavioural fear responses of heifers to different fear-eliciting situations involving humans. Appl. Anim. Behav. Sci. 131, 21-28. DOI: $10.1016 /$ j.applanim.2011.01.004

MENCH, J. A., J. MORROW-TESCH, L. R. CHU (1998): Environmental enrichment for farm animals. Lab Animal 27, 32-36.

MIKUŠ, T., O. MIKUŠ, L. KOZAČINSKI, Ž. MESIĆ (2017): Croatian meat consumer attitudes towards animal welfarefriendly products and production. Meso 19, 324-330. DOI: $10.31727 / \mathrm{m} .19 .4 .6$

NEWBERRY, R. C. (1995): Environmental enrichment: increasing the biological relevance of captive environments. Appl. Anim. Behav. Sci. 44, 229-243. DOI: 10.1016/0168-1591(95)00616-Z

NEWBY, N. C., T. F. DUFFIELD, D. L. PEARL, K. E. LESLIE, S. J. LEBLANC, M. A. G. VON KEYSERLINGK (2013): Use of a mechanical brush by Holstein dairy cattle around parturition. J. Dairy Sci. 96, 2339-2344.

DOI: $10.3168 /$ jds.2012-6016

PAVIČIĆ, Ž., M. OSTOVIĆ (2019): Animal Welfare. Naklada Slap, Jastrebarsko, Croatia (in Croatian).
PELlEY, M. C., A. LiRETTE, T. TENNESSEN (1995): Observations on the responses of feedlot cattle to attempted environmental enrichment. Can. J. Anim. Sci. 75, 631-632. DOI: $10.4141 /$ cjas $95-093$

PETHERICK, J. C., V. J. DOOGAN, B. K. VENUS, R. G. HOLROYD, P. OLSSON (2009): Quality of handling and holding yard environment and beef cattle temperament: 2. Consequences for stress and productivity. Appl. Anim. Behav. Sci. 120, 28-38.

DOI: 10.1016/j.applanim.2009.05.009

REINHARDT, V., A. REINHARDT (2002): Comfortable quarters for sheep in research institutions. In: Comfortable Quarters for Laboratory Animals. $9^{\text {th }}$ ed., (Reinhardt, V., A. Reinhardt, Eds.), Animal Welfare Institute, Washington, D.C., USA, pp. 83-88.

SUNDRUM, A., S. PADEL, G. ARSENOS, B. I. F. HENRIKSEN, M. WALKENHORST, M. VAARST (2006): Current and proposed EU legislation on organic livestock production, with a focus on animal health, welfare and food safety: a review. Proceedings of the $5^{\text {th }}$ SAFO Workshop, 1 June, Odense, Denmark, pp. 75-90.

TUCKER, C. B. (2014): Behaviour of cattle. In: The Ethology of Domestic Animals, According to the $2^{\text {nd }}$ English Edition: an Introductory Text. (Pavičić, Ž., K. Matković, Eds.), Faculty of Veterinary Medicine, University of Zagreb, Zagreb, Croatia, pp. 151-160 (in Croatian).

TUCKER, C. B. (2018): Advances in Cattle Welfare. Woodhead Publishing, Elsevier, Ltd., UK.

WELFARE QUALITY ${ }^{\circledR}$ (2009): Welfare Quality ${ }^{\circledR}$ Assessment Protocol for Cattle. Welfare Quality ${ }^{\circledR}$ Consortium, Lelystad, The Netherlands.

WILSON, S. C., F. M. MITLÖHNER, J. MORROW-TESCH, J. W. DAILEY, J. J. MCGLONE (2002): An assessment of several potential enrichment devices for feedlot cattle. Appl. Anim. Behav. Sci. 76, 259-265.

DOI: 10.1016/S0168-1591(02)00019-9

Received: 20 June 2020

Accepted: 7 September 2020

MATKOVIĆ, K., R. ŠIMIĆ, M. LOLIĆ, M. OSTOVIĆ: Utjecaj obogaćenja okoliša na neke pokazatelje dobrobiti junadi u tovu držane pri različitim gustoćama naseljenosti. Vet. arhiv 90, 575-582, 2020.

\section{SAŽETAK}

U radu je istraživan utjecaj obogaćenja okoliša pri različitim gustoćama naseljenosti na dobrobit junadi u tovu. Istraživanje je provedeno na četirima skupinama junica tijekom četveromjesečnog završnog komercijalnog tova. Junice su držane u neobogaćenom i obogaćenom okolišu pri maloj $\left(\mathrm{n}=14 ; 4,5 \mathrm{~m}^{2} /\right.$ životinji) i velikoj $(\mathrm{n}=19 ; 3,3$ $\mathrm{m}^{2} /$ Životinji) gustoći naseljenosti. Obogaćenje okoliša sastojalo se od četke za njegu i blokova soli. Dobrobit junica procijenjena je na temelju odabranih pokazatelja protokola Welfare Quality ${ }^{\circledR}$ assessment protocol for cattle. Rezultati istraživanja pokazali su da su se junice držane pri velikoj gustoći naseljenosti znakovito više $(\mathrm{P}<0,05)$ koristile materijalima za obogaćivanje okoliša u usporedbi s manjom gustoćom, dok razlike u korištenju pojedinih materijala nije bilo. Utjecaj obogaćenja okoliša na dobrobit junica uglavnom se očitovao smanjenjem izražavanja pojedinih oblika agresivnog ponašanja. Ipak, ovaj nalaz trebao bi poticati upotrebu materijala za obogaćivanje kao što su oni predstavljeni u ovom istraživanju, koji su komercijalno dostupni, relativno jeftini i jednostavni za primjenu.

Ključne riječi: junad u tovu; obogaćenje okoliša; četka za njegu; blok soli; gustoća naseljenosti; dobrobit životinja 